\title{
ANALISIS LITERASI SUKUK BAGI MAHASISWA FAKULTAS AGAMA ISLAM UNIVERSITAS ISLAM RIAU
}

\author{
Ag. Maulana ${ }^{1}$ \& Husni Thamrin ${ }^{2}$ \\ ${ }^{1 \& 2}$ Program Studi Ekonomi Syariah, Pascasarjana UIN Suska Riau \\ Email :aghe68@gmail.com,husni2017husni@gmail.com
}

\begin{abstract}
ABSTRAK
Para penggiat dunia akademik khususnya yang bergelut di dunia perekonomian tentunya sudah tidak asing lagi dengan sukuk ini. Karena adanya pengenalan teori dasar atau disebut dengan literasi sukuk kepada pelajarnya khususnya kepada mahasiswa. Hal ini dikarenakan melihat besarnya peluang sukuk yang semakin berkembang dengan pesat di setiap tahunnya. Sehingga bisa membuka pola fikir mahasiswa untuk mengatur keuangannya dengan berinvestasi sukuk. Salah satu lembaga akademik yang ada di Provinsi Riau adalah Universitas Islam Riau yang memiliki Fakultas Agama Islam yang terdapat 5 jurusan yang di antaranya prodi Ekonomi Syariah dan Perbankan Syariah yang telah mengedukasikan tentang sukuk. Rumusan masalah dalam penelitian ini adalah bagaimana literasi sukuk pada mahasiswa Ekonomi Syariah dan Perbankan Syariah FAI UIR, sedangkan tujuannya untuk mengetahui tingkat literasi sukuk pada mahasiswa kedua prodi tersebut. Jenis penelitian ini adalah penelitian lapangan (Field Research) dengan populasi dari kedua prodi tersebut sebanyak 487 mahasiswa dan sampelnya menggunakan total sampling. Adapun metode pengumpulan data melalui penyebaran angket serta di analisis dengan kriteria interpretasi score yang bersifat deskriptif. Adapun hasil penelitian ini menunjukkan bahwa literasi sukuk bagi mahasiswa dari kedua prodi ini masih dalam kategori "Cukup" dengan angka interpretasi 53,22\% pada aspek pengetahuan dan juga kategori "Cukup" pada aspek keyakinan dan pemahaman dengan angka interpretasi 59,85\%. Sedangkan pada aspek aktivitas sosialisasi tergolong "Kuat" dengan angka interpretasi 61,15\% yang merupakan menggunakan media pembelajaran di mata kuliah dan juga melalui media masa (Social Media).
\end{abstract}

Kata Kunci : Literasi, Keuangan Syariah, Sukuk.

\begin{abstract}
Activists in the academic world, especially those struggling in the world of economy, are certainly familiar with this sukuk. Because there is an introduction to basic theory or what is called sukuk literacy to students, especially students. This is due to seeing the large opportunity for the sukuk which is growing rapidly every year. So that it can open the mindset of students to manage their finances by investing in sukuk. One of the academic institutions in Riau Province is the Riau Islamic University which has a Faculty of Islamic Religion, which has 5 departments, including Islamic economics and Islamic banking study programs, which educate about sukuk. The formulation of the problem in this study is how the sukuk literacy in students of Islamic economics and Islamic banking FAI UIR, while the goal is to determine the level of sukuk literacy in students of the two study programs. This type of research is field research with a population of both study programs as many as 487 students and the sample uses total sampling. The data collection method was through distributing questionnaires and analyzed with criteria scoring interpretation descriptive. The results of this study indicate that the sukuk literacy for students from these two study programs is still in the "adequate" category with an interpretation rate of 53.22\% in the knowledge aspect and also the "adequate" category on the aspect of belief and understanding with an interpretation rate of $59.85 \%$. Whereas in the aspect of socialization activities are classified as "strong" with an interpretation rate of $61.15 \%$ which is using learning media in courses and also through Social Media.
\end{abstract}

Keywords : Literacy, Islamic Financial, Sukuk. 


\section{PENDAHULUAN}

Literasi dewasa ini menjadi istilah yang popular. Istilah literasi ini sering diungkapkan diberbagai kesempatan, baik pembahasan secara langsung maupun di media sosial. Literasi merupakan menjadi suatu hal yang amat penting, sehingga pemerintah melalui kementerian Pendidikan dan Kebudayaan membuat sebuah gerakan yang khusus berkaitan dengan literasi di berbagai sektor baik dibidang pendidikan, perekonomian dan sektor lainnya.

Pada sektor perekonomian banyak lembaga terkait yang mengedukasikan pemahaman tentang keuangan baik secara konvensional maupun keuangan syariah. Tidak hanya dunia perbankan, lembaga keuangan syariah non bank pun juga ikut serta. Hal ini juga di lakukan oleh para akademisi untuk meningkatkan pemahaman kepada pelajarnya khususnya yang bergelut di bidang perekonomian tentang lembaga keuangan tersebut.

Berbicara industri keuangan syariah salah satunya adalah pasar modal syariah yang saat ini juga turut berkembang dewasa ini. Pasar modal syariah adalah menjalankan fungsi intermediasi dengan menyediakan produk investasi berbasis Islam yang menghubungkan para pihak tersebut, pihak yang membutuhkan dana dengan pemilik dana. Pihak yang membutuhkan dana akan menerbitkan produk investasi (Efek) yang disesuaikan dengan jenis kebutuhannya karena setiap Efek mempunyai karakteristik yang ber beda. Efek syariah yang diterbitkan akan ditawarkan ke pada investor melalui mekanisme intermediasi di pasar modal Islam. Penerbit Efek sebagai pihak pemasok (supply side), Investor sebagai pihak pembeli Efek (demand side) dan Bursa Efek sebagai pihak penyelenggara fungsi intermediasi di pasar modal syariah.

Salah satu efek syariah yang ada pada pasar modal syariah adalah sukuk. Yang mana sukuk merupakan efek syariah yang berbasis sekuritisasi aset (Asset Securitization). Pemahaman tentang sukuk ini sangatlah penting baik kalangan investor maupun mahasiswa. Karena calon investor harus mengetahui regulasi sukuk yang terdapat pada efek syariah saat ini. Sehingga mampu mempraktikkannya di kemudian hari. Karena sukuk merupakan sebuah investasi yang sangat berkembang dengan signifikan di setiap tahunnya seperti yang tergambar pada tabel grafik berikut ini.

\section{Gambar 1. Perkembangan Sukuk Korporasi Oktober 2020}

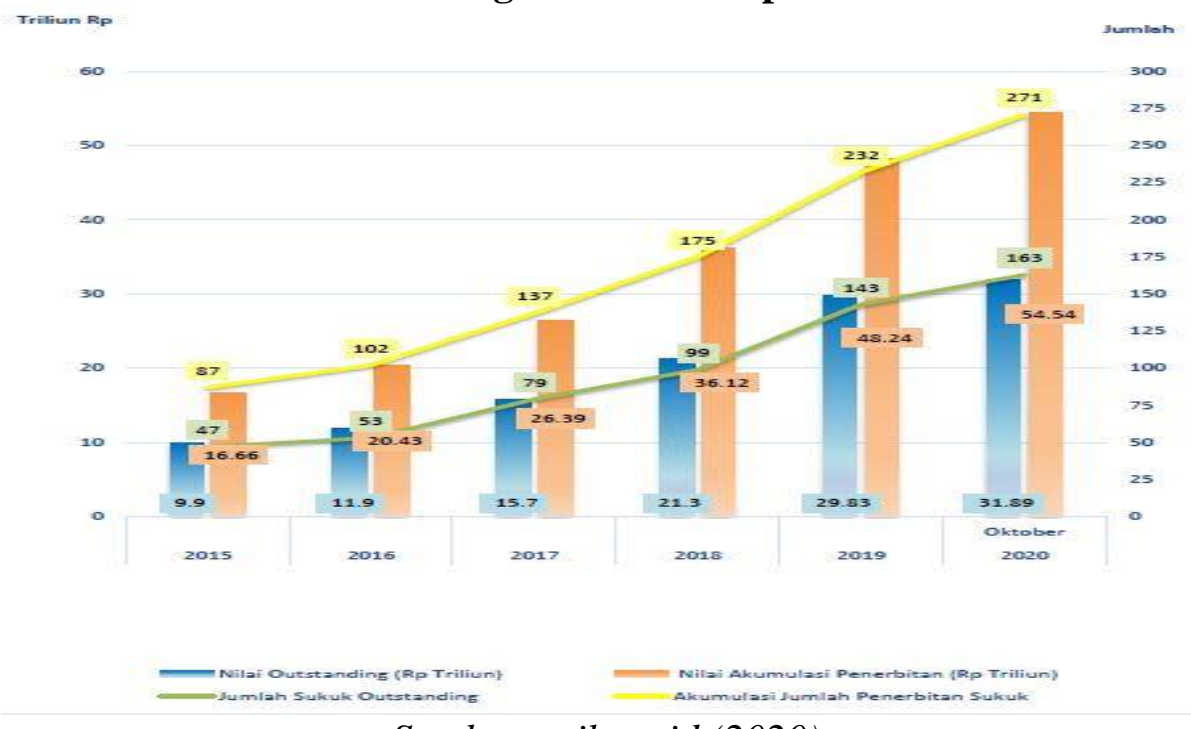

Sumber : ojk.go.id (2020) 
Berdasarkan data di atas terlihat jelas bahwasanya pada bulan Oktober 2020 jumlah penerbitan sukuk mencapai angka 271. Dan setiap tahunnya memiliki kenaikan yang signifikan. Oleh karena itu sukuk sangat berpeluang besar untuk berinvestasi serta mempunyai profitabilitas yang bagus. Sehingga perlunya pemahaman sejak dini kepada pelaku ekonomi maupun mahasiswa untuk menciptakan kehidupan yang layak di kemudian hari.

Pada sektor akademik khususnya yang bergelut di dunia perekonomian tentunya sudah tidak asing lagi dengan sukuk ini. Karena adanya pengenalan teori dasar kepada pelajarnya khususnya kepada mahasiswa. Hal ini dikarenakan melihat besarnya peluang sukuk yang semakin berkembang dengan pesat di setiap tahunnya. Sehingga bisa membuka pola fikir mahasiswa untuk mengatur keuangannya dengan berinvestasi sukuk. Karena sukuk juga termasuk dalam kategori efek pendapatan tetap.

Universitas Islam Riau merupakan salah satu kampus/perguruan tinggi terbesar di Riau yang memiliki 10 fakultas serta didalamnya terdapat 42 program studi yang salah satunya adalah Fakultas Agama Islam yang memiliki 5 program studi yang diantaranya program studi Ekonomi Syariah dan Perbankan Syariah yang menjadi tempat penelitian ini. Karena di Fakultas Agama Islam hanya kedua program studi inilah yang mempelajari Manajemen Investasi Syariah.

Melalui mata kuliah Manajemen Investasi ini, salah satu pembahasannya yaitu membahas tentang sukuk. Dengan metode pembelajaran yang sesuai dengan kemampuan dosennya. Sehingga sedikit banyaknya mahasiswa mengetahui serta memahami tentang sukuk. Karena sukuk merupakan bagian dari ilmu ekonomi syariah yang harus di fahami oleh mahasiswa kedua program studi ini.

\section{TINJAUAN PUSTAKA}

\section{Pengertian Literasi}

Definisi literasi dalam konteks Programme for International Student Assessmen (PISA) 2015 mengalami evolusi yang cukup penting. Dalam PISA 2015 istilah literasi sains disarankan untuk diubah menjadi literasi saintifik. Literasi saintifik adalah kemampuan untuk terlibat isu-isu dan ide-ide yang terkait dengan ilmu pengetahuan sebagai warga reflektif. Dalam bidang sains, literasi juga dapat diartikan kemampuan memahami, berpikir, dan mengaplikasikan konsep dan perspektif sains dalam berbagai kejadian. (Abidin, 2017)

Islam merupakan sebuah agama yang menjadi dorongan terhadap literasi untuk membudayakan budaya literasi di kalangan umatnya. Hal tersebut tidak lepas dari sejarah turunnya kitab suci AlQuran itu sendiri yakni wahyu yang pertama kali turun kepada Nabi Muhammad SAW. tentang ilmu pengetahuan, yaitu "Iqro" yang bermakna perintah untuk membaca. (Adisaputaro, 2018)

Otoritas Jasa Keuangan (OJK) menyatakan bahwa secara definisi literasi dapat diartikan sebagai kemampuan untuk memahami, jadi literasi keuangan adalah kemampuan mengelola dana yang dimiliki agar berkembang serta hidup bisa lebih sejahtera dimasa depan nanti, misi penting dari program literasi keuangan adalah untuk melakukan edukasi dibidang keuangan kepada masyarakat Indonesia agar mengelola keuangan secara dapat cerdas, supaya rendahnya pengetahuan tentang industri keuangan dapat diatasi dan masyarakat tidak mudah tertipu pada produk-produk investasi yang menawarkan keuntungan tinggi dalam jangka pendek tanpa mempertimbangkan resikonya Jadi dari definisi-definisi 
tersebut dapat dipahami bahwa literasi keuangan merupakan salah satu kebutuhan dasar bagi setiap orang agar terhindar dari masalah keuangan.(Nuraini, $\mathrm{dkk}, 2020$ )

Literasi keuangan adalah kemampuan (kecakapan) perorangan dalam menentukan sebuah keputusan yang efektif yang berhubungan dengan keuangannya. Literasi keuangan ini membantu individu agar terhindar dari masalah keuangan, terutama yang dikarenakan akibat kesalahan dari pengelolaan keuangan. Literasi keuangan dalam bentuk pemahaman terhadap semua aspek-aspiek keuangan pribadi, bukan ditujukan untuk mempersulit atau mengikat orang dalam menikmati kehidupannya. Akan tetapi dengan literasi keuangan individu atau keluarga dapat menikmati hidup dengan sumberdaya keuangannya dengan tepat. (Yushita, 2017)

Menurut Otoritas Jasa Keuangan (OJK) literasi keuangan merupakan rangkaian proses atau aktivitas untuk meningkatkan pengetahuan (knowledge), keyakinan (confidence), keterampilan (skill) konsumen dan masyarakat luas, sehingga mereka mampu mengelola keuangan dengan lebih baik. Terhambatnya pembangunan ekonomi negara diakibatkan kurangnya akses ke lembaga keuangan, sehingga banyak masyarakat yang terjebak dalam modus kejahatan dari penjual produk-produk keuangan. (Subardi \& Yuliafitri, 2019)

Pengenalan dan penanaman pengetahuan dan keterampilan keuangan syariah sejak dini melalui pendidikan dasar akan membentuk mind-set dan pola pikir peserta didik sejak dini tentang aktifitas keuangan mereka dalam kehidupan sehari-hari, sehingga setiap aktifitas yang terkait bidang ekonomi keuangan akan dipengaruhi oleh nilai- nilai ekonomi syariah sampai dengan dewasa. (Asyhad \& Handono, 2017)

Tujuan program pembangunan literasi keuangan syariah adalah untuk memperluas dan meningkatkan pengetahuan, pemahaman dan peran serta masyarakat dalam penggunaan produk dan jasa keuangan syariah. Literasi keuangan syariah diharapkan mampu meningkatkan pengetahuan masyarakat serta mengubah perilaku masyarakat dalam mengelola keuangan secara lebih baik, mampu dan cerdas memilih investasi yang halal dan menguntungkan, mampu mencegah masyarakat mengikuti investasi bodong. (Nasution \& Marlya, 2019)

\section{Sukuk}

Dalam Peraturan Badan Pengawas Pasar Modal (BAPEPAM) dan Lembaga Keuangan (LK) mengartikan Sukuk adalah Efek Syariah berupa sertifikat atau bukti kepemilikan yang bernilai sama dan mewakili bagian yang tidak tertentu (tidak terpisahkan atau tidak terbagi (syuyu'/undivided share)) atas:

1. Aset berwujud tertentu (a'yan maujudat);

2. Nilai manfaat atas aset berwujud (manafiul a'yan) tertentu baik yang sudah ada maupun yang akan ada;

3. Jasa (al khadamat) yang sudah ada maupun yang akan ada;

4. Aset proyek tertentu (maujudat masyru' mu'ayyan); dan/atau

5. Kegiatan investasi yang telah ditentukan (nasyath ististmarin khashah).

Sedangkan OJK mengartikan Sukuk adalah Efek Syariah berupa sertifikat atau bukti kepemilikan yang bernilai sama dan mewakili bagian yang tidak terpisahkan atau tidak terbagi (syuyu'/undivided share), atas aset yang mendasarinya. 
Berdasarkan emiten atau lembaga penerbitan sukuk, sukuk dapat dibagi menjadi dua macam, yaitu sebagai berikut:

1. Sukuk korporasi (Corporate Sukuk). Sukuk korporasi ialah sukuk yang diterbitkan oleh korporasi atau perusahaan, baik perusahaan swasta maupun BUMN.

2. Sukuk negara (Sovereign Sukuk). Yang mana Sukuk yang dikeluarkan oleh pemerintah, dalam hal ini Kementrian Keuangan Republik Indonesia. (Fasa, 2016)

Menurut Abdallah (2018) Sukuk adalah salah satu jenis Efek syariah yang paling dikenal dan paling banyak dibahas oleh para ahli keuangan Islam. Sukuk tidak sama dengan obligasi meskipun keduanya termasuk Efek pendapatan tetap karena obligasi adalah Efek berbasis surat utang (debt securities) sedangkan sukuk adalah Efek syariah berbasis sekuritisasi aset (asset securitization). Jadi, sangat tidak tepat apabila sukuk disebut sebagai obligasi syariah karena sukuk menggunakan akad pembiayaan sedangkan obligasi menggunakan akad pinjaman. Jadi, sukuk adalah Efek syariah berbasis sekuritisasi aset dan termasuk ke dalam Efek pendapatan tetap.

Yang dimaksud dengan sekuritisasi aset adalah produk investasi yang merupakan hasil konversi aset riil menjadi produk keuangan (sekuritas) untuk jangka waktu tertentu. Karena termasuk sekuritisasi aset, maka sukuk harus mempunyai aset yang jelas sebagai dasar penerbitannya (underlying asset). Yang dimaksud dengan Efek pendapatan tetap adalah Efek yang memberikan kepastian dan informasi yang tetap kepada investor pada saat awal penerbitan Efek tentang empat hal berikut: (Abdallah, 2018)

1. Waktu atau umur jatuh tempo (maturity date).
2. Besaran nilai pokok pembiayaan (par atau principal value) produk,

3. Besaran keuntungan investasi (return atau couponrate) dan

4. Waktu atau periode pembayaran keuntungan dan pengembalian principal value

Karena termasuk produk pendapatan tetap maka sukuk harus sudah memberikan informasi yang jelas dan diketahui oleh investor di depan terkait besaran minimal nilai investasi, umur produk, keuntungan investasi yang akan diterima, dan kapan pembayaran keuntungan akan dilakukan. (Abdallah, 2018)

Setiap penerbitan sukuk akan melibatkan beberapa pihak sebagai berikut:

1. Pemilik aset yang dijadikan dasar penerbitan sukuk disebut originator dan biasanya sekaligus sebagai penerbit sukuk (issuer) atau emiten.

2. Special Purpose Vehicle (SPV) yaitu perantara wakil emiten yang bersifat sementara selama jangka waktu sukuk. Pada praktiknya, SPV adalah bagian dari internal organisasi perusahaan originator dan penerbit sukuk bukan lembaga terpisah.

3. Wali amanat adalah lembaga independen yang men jadi wakil investor untuk berhubungan dengan pihak penerbit sukuk.

4. Dewan Pengawas Syariah (DPS) atau tim ahli syariah emiten.

5. Lembaga pemeringkat Efek yang menilai kualitas sukuk yang diterbitkan.

\section{Perbedaan Sukuk dan Obligasi Syariah}

Perbedaan pokok antara sukuk dengan obligasi syariah adalah berupa konsep imbalan dan bagi hasil sebagai penggganti bunga, adanya transaksi 
pendukung berupa asset yang menjadi dasar penerbitan sukuk dan akad berdasarkan prinsip syariah. Obligasi syariah ada diatur dalam fatwa DSN-MUI antara lain DSN MUI NO. 32/DSNMUI/IX/2002 tentang Obligasi Syariah, No. 33/DSN-MUI/IX/2002 tentang Obligasi Syariah Mudharabah, No. 59/ DSN-MUI/V/2007 tentang Obligasi
Syariah Mudharabah Konversi. Beberapa jenis sukuk yang telah dikenal scara internasional yaitu sukuk ijarah, sukuk mudharabah, sukuk musyarakah, sukuk istisna'. Ada juga Obligsi Syariah Mudharabah Konversi antara lain sukuk korporasi, surat berharga syariah negara. (Awaluddin, 2016)

Tabel 1. Perbedaan Sukuk dan Obligasi

\begin{tabular}{|c|c|}
\hline Sukuk & Obligasi \\
\hline \multicolumn{2}{|c|}{ Efek pendapatan tetap } \\
\hline Sekuritas Aset & Surat Utang \\
\hline Pembiayaan & Pinjaman \\
\hline Harus Ada Underlying asset & Tidak Harus Ada \\
\hline Efek Syariah & Efek non-Syariah \\
\hline
\end{tabular}

Sumber : Abdallah, (2018)

\section{Karakteristik Sukuk}

Sebagai sebuah produk ekonomi syariah yang berkembang sejak zaman pertengahan, karaktristik sukuk dapat dirinci antara lain: (Hanapi, 2019)

1. Dalam penertbitannya memerlukan adanya underlying asset.

2. Underlying asset merupakan bukti kepemilikan.

3. Jenis akad yang digunakan dalam penerbitan sukuk menjadi dasar imbal hasil (return) yang diberikan berupa upah/sewa (ujrah), selisih harga lebih (margin), dan bagi hasil.

4. Tidak boleh ada unsur riba, gharar, dan maysir.

5. Penggunaan dana harus sesuai dengan prinsip syariah

\section{Penerbit (Issuer) Sukuk}

Peraturan penerbitan sukuk pemerintah berbeda dengan peraturan penerbitan sukuk korporasi. Di Indonesia, penerbitan sukuk oleh pemerintah diatur Undang-Undang (UU) RI No. 19 tahun 2008 tentang penerbitan Surat Berharga
Syariah Negara, sedangkan penerbitan sukuk oleh korporasi diatur regulasi yang dikeluarkan oleh OJK (saat ini, peraturan OJK No. 18/ POJK.04/2015 tentang Penerbitan dan Persyaratan Sukuk).

Penerbitan sukuk oleh pemerintah terdiri atas pemerin tah pusat dan pemerintah daerah atau sukuk (pemerintah) daerah (municipal sukuk). Pemerintah dapat mener bitkan sukuk dalam mata uang lokal (government sukuk) atau mata uang asing (sovereign sukuk) yang diterbitkan di negara lain. Pada dasarnya, sukuk adalah Efek yang nilai per unitnya sangat besar sehingga bukan untuk investor ritel. Pemerintah Indonesia melakukan terobosan dengan menerbitkan sukuk dalam pecahan kecil, yaitu sukuk (negara) ritel dan sukuk (negara) tabungan ritel, yang ditujukan untuk investor ritel individu. Pada saat ini, sukuk ritel menggunakan pecahan per unit sebesar Rp. 5.000.000. dan sukuk tabungan ritel dengan pecahan per unitnya adalah Rp. 2.000.000. (Abdallah, 2018)

\section{Landasan Hukum Sukuk}

Adapun landasan hukum tentang sukuk berlandaskan kepada Al-Quran, 
Hadis, serta Fatwa DSN MUI adalah sebagai berikut : (Zulkifli, 2015)

1. Firman Allah dalam Surah AlBaqarah ayat 275 yang berbunyi sebagai berikut.

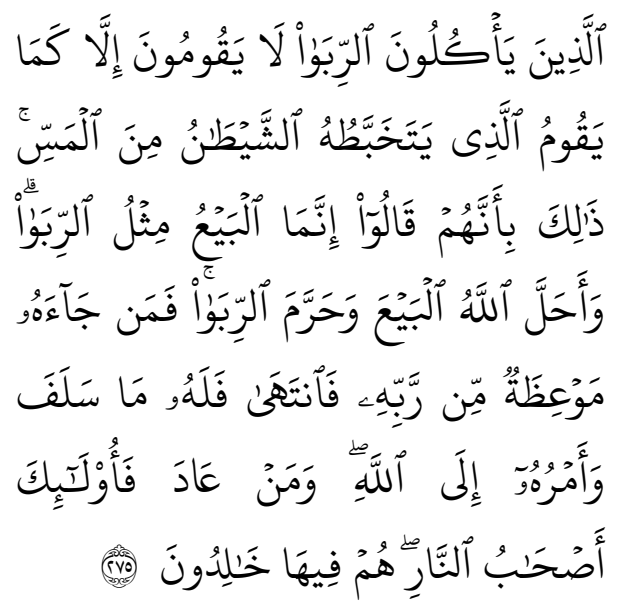

Artinya : "Orang-orang yang makan (mengambil) riba tidak dapat berdiri melainkan seperti berdirinya orang yang kemasukan syaitan lantaran (tekanan) penyakit gila. Keadaan mereka yang demikian itu, adalah disebabkan mereka berkata (berpendapat), sesungguhnya jual beli itu sama dengan riba, padahal Allah telah menghalalkan jual beli dan mengharamkan riba. Orangorang yang telah sampai kepadanya larangan dari Tuhannya, lalu terus berhenti (dari mengambil riba), maka baginya apa yang telah diambilnya dahulu (sebelum datang larangan); dan urusannya (terserah) kepada Allah. Orang yang kembali (mengambil riba), maka orang itu adalah penghunipenghuni neraka; mereka kekal di dalamnya". (QS. Al-Baqarah : 275)

2. Sabda Rasulullah SAW : "Tiga bentuk usaha yang didalamnya mengandung barakah: yaitu jualbeli secara tangguh, mudharabah/kerjasa ma dalam bagi hasil dan mencampur gandum dengan kedelai (hasil keringat sendiri) untuk kepentingan keluarga bukan un tuk dijual. (HR. Ibnu Majah)

3. Fatwa DSN-MUI No. 137/DSNMUI/IX/2020 Tentang Sukuk adalah sebagai berikut :

a. Sukuk adalah Surat Berharga Syariah (Efek Syariah) berupa sertifikat atau bukti kepemilikan yang bernilai sama, dan mewakili bagian kepemilikan yang tidak bisa ditentukan batas-batasnya (musya') atas aset yang mendasarinya (Aset Sukuk/Ushul al- Shukuk) setelah diterimanya dana sukuk, ditutupnya pemesanan dan dimulainya penggunaan dana sesuai peruntukannya.

b. Aset Sukuk (Ushul Al-Shukuk) adalah Aset yang menjadi dasar penerbitan Sukuk yang terdiri atas aset berwujud (al$\left.a^{\prime} y a n\right)$, nilai manfaat atas aset berwujud (Manali' Al-A'yan), jasa (Al-Khadamat), aset proyek tertentu (maujudat masyru' mu'ayyan) dan/atau aset kegiatan investasi yang telah ditentukan (nasyath istitsmar khashsh).

\section{Jenis Sukuk Berdasarkan Akad}

Adapun jenis sukuk berdasarkan akadnya adalah sebagai berikut : (Abdallah, 2018)

1. Sukuk Ijarah. Sukuk Ijarah adalah sukuk yang meng gunakan akad sewa sebagai dasar penerbitannya. Manfaat dari aset yang mendasari penerbitan sukuk ijarah yang menjadi objek transaksi. Karena akad sewa maka keuntungan yang akan diterima oleh 
investor nilainya tetap dalam ukuran persentase tertentu. Sumber pendapatan (Income Stream) sukuk ijarah yang akan dikonversi menjadi keuntungan yang dibagikan kepada investor berasal dari ujrah penyewaan underlying asset.

2. Sukuk Mudharabah. Sukuk mudharabah adalah sukuk yang menggunakan skema akad mudharabah sebagai dasar penerbitannya. Investor sebagai pemilik modal (shahibul al-mal) dan penerbit sukuk (emiten) sebagai pengelola aset (mudharib). Dalam hal ini, yang dimaksud dengan mudharib adalah pengelola usahanya yaitu manajemen perusahaan, sedangkan perusahaan adalah bentuk kerja samanya.

3. Sukuk Wakalah. Sukuk wakalah adalah sukuk yang menggunakan skema akad wakalah sebagai dasar penerbitannya. Investor sebagai pihak pemberi kuasa (muwakkil) dan emiten atau penerbit sukuk sebagai penerima kuasa (wakil). Keuntungan investasi berasal dari hasil pengelolaan portofolio aset oleh emiten Karena menggunakan akad wakalah, maka nilai keuntungan yang akan diterima investor adalah tetap yang dituangkan dalam angka persentase. Sebagai wakil, emiten harus mengelola dana sesuai dengan jenis portofolio aset yang disepakati dan disampaikan kepada investor. Portofolio aset bisa fleksibel ber dasarkan komposisi yang disetujui investor. Bahkan, asetnya bisa diubah atau diganti sebelum jatuh tempo sepanjang tidak mengubah struktur akad wakalah secara keseluruhan.

\section{METODE PENELITIAN}

\section{Jenis Penelitian}

$\begin{array}{ccc}\text { Penelitian } & \text { ini } & \text { merupakan } \\ \text { penelitian lapangan } & \text { (Field } & \text { Research). }\end{array}$ Jenis penelitian yang digunakan dalam penelitian ini adalah jenis penelitian kualitatif deskriptif yakni jenis penelitian yang disusun dalam rangka memberikan gambaran secara sistematis tentang informasi ilmiah yang berasal dari subjek atau objek penelitian.

Penelitian ini dilaksanakan pada 2 (Dua) program studi di Fakultas Agama Islam Universitas Islam Riau yakni Prodi Ekonomi Syariah dan Perbankan syariah. Adapun yang menjadi subjek dalam penelitian ini adalah mahasiswa Prodi Ekonomi Syariah dan Perbankan Syariah. Sedangkan yang menjadi objek adalah literasi sukuk.

\section{Populasi dan Sampel}

Adapun jumlah keseluruhan mahasiswa Ekonomi Syariah dan Perbakan Syariah yang akan menjadi populasi dalam penelitian ini sebesar 487 mahasiswa. Sedangkan sampel dalam penelitian ini menggunakan tekhnik Total Sampling yang mana seluruh populasi di anggap menjadi sampel. (Sugiyono, 2018)

\section{Teknik Analisis Data}

Setelah data berhasil dikumpulkan, selanjutnya penulis menganalisa data tersebut dengan menggunakan metode interpretasi skor. Adapun kriteria interpretasi skor adalah sebagai berikut : (Ridwan, 2018)

\section{Gambar 2. Skala Interpretasi Skor}

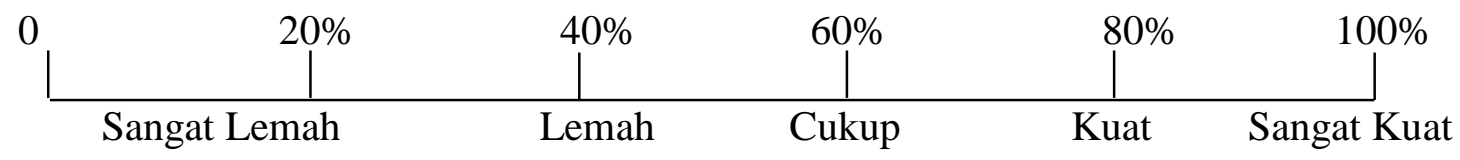


Keterangan :

Kriteria Interpretasi Skor :

Angka 0\% - 20\% = Sangat Lemah

Angka 21\% - $40 \%=$ Lemah

Angka 41\% - 60\% = Cukup

Angka 61\% - 80\% = Kuat

Angka $81 \%$ - $100 \%=$ Sangat Kuat

\section{HASIL PENELITIAN}

\section{Identitas Responden}

Berdasarkan hasil rekapitulasi data responden dari jumlah keseluruhan mahasiswa Ekonomi Syariah dan Perbankan Syariah hanya terkumpul sebanyak 99 orang yang disebabkan oleh factor jarak yang terlalu jauh dari tempat penelitian.

Adapun identitas berdasarkan indikator diantaranya : Pertama, berdasarkan program Studinya menunjukkan bahwa responden dari kedua program studi tidak terlalu berselisih yaitu prodi ekonomi syariah berjumlah 55 orang atau sebesar 55,5\%. Sedangkan prodi perbankan syariah sebanyak 44 orang atau sebesar $44,5 \%$. Kedua, berdasarkan jenis kelamin bahwa perempuan lebih dominan dengan jumlah 74 orang atau sebesar $74,7 \%$, sedangkan laki-laki berjumlah 25 orang atau sebesar 25,3\%. Ketiga, berdasarkan tingkatan semesternya menunjukkan bahwa pada semester 5 yang lebih banyak mencapai 44 orang atau sebesar $44,4 \%$, sedangkan sisanya tersebar di semester 1 , semester 3 , semester 7 dan semester lanjutan secara berturut berjumlah 13 orang $(7,1 \%), 19$ orang $(19,2 \%), 16$ orang $(16,2 \%)$, dan 13 orang $(13,1 \%)$.

\section{Analisis Data}

\section{Aspek Pengetahuan Sukuk}

Dari hasil uji tanggapan responden dapat di ketahui bahwasanya pengetahuan mahasiswa Ekonomi Syariah dan
Perbankan Syariah tentang sukuk memperoleh jawaban "Setuju" dengan angka persentase sebesar 53,22\%. Item pernyataan yang banyak dipilih terdapat pada pernyataan "Sukuk sebagai Efek Syariah berupa sertifikat atau bukti kepemilikan yang bernilai sama dan mewakili bagian yang tidak tertentu". Pernyataan ini merupakan defenisi sukuk dari Peraturan Badan Pengawas Pasar Modal (BAPEPAM) dan Lembaga Keuangan (LK) Nomor IX.A.13.

\section{Aspek Keyakinan dan Pemahaman Sukuk}

Berdasarkan hasil uji tanggapan responden dapat diketahui bahwasanya pemahaman dan keyakinan mahasiswa Ekonomi Syariah dan Perbankan Syariah tentang sukuk memperoleh tanggapan "Setuju" dengan jumlah persentase sebesar $59,85 \%$. Adapun item pernyataan yang dominan pada aspek keyakinan dan pemahaman tentang sukuk ini terdapat 2 item pernyataan yaitu pada pernyataan "Sukuk merupakan produk investasi yang berbasis syariah dan prinsip dan akad yang berbeda-beda sesuai dengan kondisi investor" dan pernyataan "Syarat dan prosedur berinvestasi sukuk lebih aman dan mudah".

\section{Aspek Aktivitas Sosialisasi Tentang Sukuk}

Adapun hasil uji tanggapan responden dapat diketahui bahwasanya aktivitas sosialisasi kepada mahasiswa Ekonomi Syariah dan Perbankan Syariah tentang sukuk juga memperoleh tanggapan "Setuju" dengan angka persentase $61,15 \%$. Adapun aktivitas sosialisasi yang dominan pada aspek ini berdasarkan tanggapan responden yaitu melalui "Mata Kuliah Program Studi" dan "Informasi Media Masa (Social Media)".

\section{PEMBAHASAN}

Penelitian ini membahas tentang literasi sukuk bagi mahasiswa Fakultas 
Agama Islam Universitas Islam Riau khususnya pada mahasiswa Program Studi Ekonomi Syariah dan Program Studi Perbankan Syariah yang mana hanya kedua program studi ini yang memiliki akses literasi sukuk kepada mahasiswa.
Syariah dan Perbankan Syariah memiliki tingkat pengetahuan yang dikategorikan cukup tentang sukuk. Hal ini buktikan dengan angka persentase dari hasil uji responden hanya sebesar 53,22\% berdasarkan skala interpretasi berikut ini :

Berdasarkan analisis data di atas, mahasiswa Program Studi Ekonomi

\section{Gambar 3. Pengukuran Interprstasi Aspek Pengetahuan}

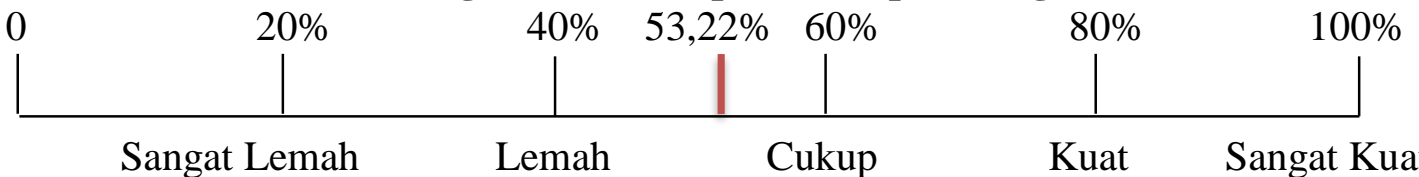

Dari gambar di atas posisi angka 53,22\% pada tingkat pengetahuan berada di interval $41 \%$ - $60 \%$ yang berarti dalam kategori cukup. Oleh karena itu perlunya peningkatan pengetahuan tentang sukuk kepada mahasiswa Program Studi Ekonomi Syariah dan Perbankan Syariah ini.

Adapun tingkat keyakinan dan pemahaman tentang sukuk pada mahasiswa Program Studi Ekonomi Syariah dan Perbankan Syariah juga dikateogrikan kepada tingkatan cukup tentang sukuk yang sepadan dengan pengetahuannya yang dibuktikan dengan angka interpretasi sebesar 59,85\% seperti pada gambar berikut ini :

Gambar 4. Pengukuran Interpretasi Aspek Keyakinan dan Pemahaman

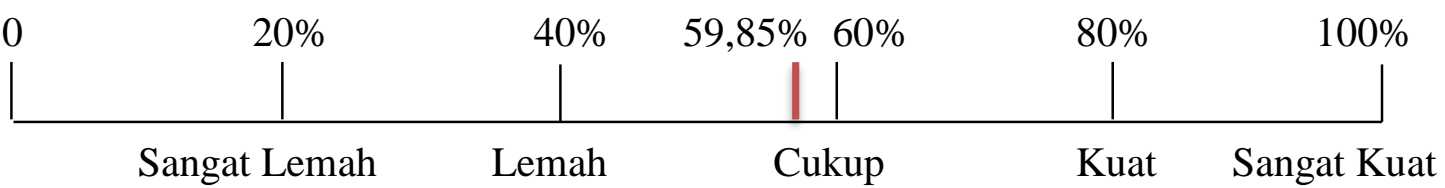

Berdasarkan gambar di atas angka Program Studi Ekonomi Syariah dan interpretasi tingkat keyakinan dan Perbankan Syariah ini dikategorikan kuat. pemahaman tentang sukuk pada Artinya mahasiswa Program Studi mahasiswa Program Studi Ekonomi Ekonomi Syariah dan Perbankan Syariah Syariah dan Perbankan Syariah menunjukkan di antara angka $41 \%-60 \%$ yang berarti tingkat pemahamannya tentang sukuk masih cukup. Hal ini masih perlu di tingkatkan lagi seiring dengan tingkat pengetahuannya.

Sedangkan tingkat aktivitas ini mengetahui serta memahami tentang sukuk melalui aktivitas sosialisasi dari program studi yang berupa mata kuliah dan juga melalui media masa (Social Media). Hal ini dapat di buktikan dengan angka interpretasi sebesar $61,15 \%$ yang terlihat pada gambar berikut ini : sosialisasi tentang sukuk pada mahasiswa

Gambar 5. Pengukuran Interpretasi Aspek Aktivitas Sosialisasi

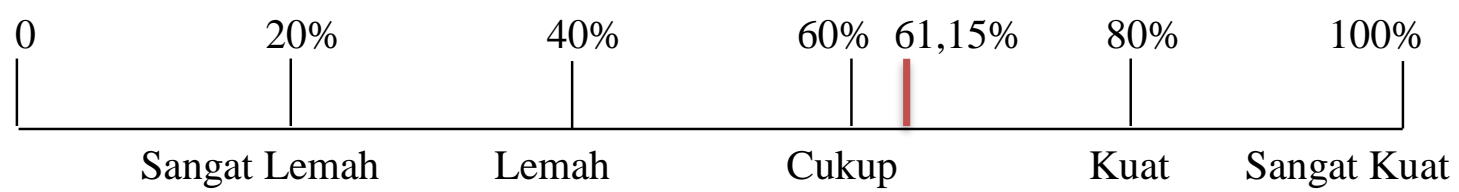


Posisi angka interpretasi aspek aktivitas sosialisasi ini berada pada antara angka $61 \%$ - 80\% yang bermakna kuat seperti yang telah dijelaskan sebelumnya. Oleh karena itu perlu di pertahankan dan di tingkatkan lagi media literasi tentang sukuk yang digunakan.

\section{KESIMPULAN}

Berdasarkan hasil penelitian ini dapat disimpulkan bahwa tingkat literasi sukuk pada mahasiswa Fakultas Agama Islam Universitas Islam Riau khususnya mahasiswa Program Studi Ekonomi Syariah dan Perbankan Syariah dilihat dari: Pertama, aspek pengetahuan mahasiswa tentang sukuk masih berada pada kategori "Cukup". Kedua, dari segi aspek keyakinan dan pemahaman mahasiswa tentang sukuk, juga masuk kedalam kategori "Cukup". Ketiga, pemahaman dari aspek aktivitas sosialisasi masuk kedalam kategori "Kuat". Oleh karena itu, mahasiswa Fakultas Agama Islam diharapkna untuk bisa meningkatkan lagi tingkat pengetahuan serta pemahamannya mengenai sukuk dengan strategi literasi sukuk yang lebih bervariasi lagi selain dari pembelajaran di kelas seperti edukasi langsung dari lembaga terkait agar mahasiswa lebih memahami secara mendalam tentang sukuk.

\section{DAFTAR PUSTAKA}

Abdallah, Irwan. 2018. Pasar Modal Syariah. Elex Media Komputindo. Jakarta

Abidin, Yunus. Dkk. 2017. Pembelajaran Literasi. Bumi Aksara. Jakarta

Adisaputaro, M Ridho. 2018. Semangat Literasi Dalam Pandangan Islam. dalam https://js.ugm.ac.id

Ashyad, M. \& Handono, Wahyu Agung. 2017. Urgensi Literasi Keuangan Syariah Pada Pendidikan Dasar.
Jurnal MIYAH : Jurnal Studi Islam. 13(1). 126-143

Awaluddin. 2016. Pasar Modal Syariah : Analisis penawaran efek syariah di bursa efek Indonesia. Jurnal Maqdis : Jurnal Kajian Ekonomi Islam. 1(2). 137-150

Fasa, Muhammad Iqbal. 2016. SUKUK: Teori dan Implementasi. Jurnal Li Falah : Jurnal Studi ekonomi dan Bisnis Islam. 1(1). 80-94

Hanapi, Hapil, 2019, Penerapan Sukuk dan Obligasi di Indonesia, Jurnal Ilmu Akuntansi dan Bisnis Syariah, 1(2), 147-162

Nuraini, Putri. Alfani, Mufti H. Hamzah, Zulfadli. 2020. Literasi Produk Perbankan Syariah Bagi Guru Pondok Pesantren Di Kota Pekanbaru. Jurnal COSTING : Jurnal of Economic, Business and Accounting. 4(1). 317-325

Nasution, A. Witi \& Fatira AK, Marlya. 2019. Analisis Faktor Kesadaran Literasi Keuangan Syariah Mahasiswa Keuangan dan Perbankan Syariah. Jurnal EQUILIBRIUM : Jurnal Ekonomi Syariah, 7(1). 40-63

Ridwan. 2018. Dasar-Dasar Statistika, Alfabeta. Bandung

Subardi, Hani Meilita P. \& Yuliafitri, Indri. Efektivitas Gerakan Literasi Keuangan Syariah Dalam Mengedukasi masyarakat memahami produk keuangan Syariah. Jurnal Banque Syar'I : Jurnal Ilmiah Perbakan Syariah. 5(1). 31-44

Sugiyono. 2018. Metode Penelitian Kuantitatif, Kualitatif, dan $R \& D$. Alfabeta. Bandung

Yushita, Amanita Novi. 2017. Pentingnya Literasi Keuangan Bagi Pengelolaan Keuangan Pribadi, 
2021, Jurnal Tabarru' : Islamic Banking and Finance 4 (1) : 1 - 12

Jurnal NOMINAL : Barometer

Riset Akuntansi dan Manajemen.

1(1). 11-26

Zulkifli. 2015. Lembaga Keuangan

Syariah. Pusat Kajian Pendidikan

Islam FAI UIR. Pekanbaru 